\title{
Tourism Industry and Women's Employment Mobility in the Special Economic Zone (SEZ) of Mandalika Kuta Lombok
}

\author{
Syafruddin Syafruddin ${ }^{1, *}$ (D), Hairil Wadi ${ }^{1}$ (D), dan Suud Suud ${ }^{1}$ (i) \\ ${ }^{1}$ Department of Sociology Education, Faculty of Teacher Training and Education, \\ University of Mataram, 83125, Mataram, Indonesia \\ *Corresponding Author: syafruddin_fkip@unram.ac.id
}

\section{ARTICLE INFO}

\section{Publication Info:}

Research Article

How to cite:

Syafruddin, S., Wadi, H., \& Suud, S. (2020). Tourism Industry and Women's Employment Mobility in the Special Economic Zone (SEZ) of Mandalika Kuta Lombok.

Society, 8(1), 136-146.

DOI : 10.33019/society.v8i1.175

Copyright (C) 2020. Owned by Author(s), published by Society

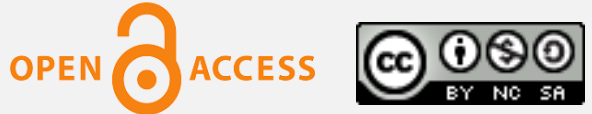

This is an open-access article.

License: Attribution-

NonCommercial-ShareAlike (CC BY-NC-SA)

Received: May 4, 2020;

Accepted: May 27, 2020;

Published: June 4, 2020;

\section{ABSTRACT}

This study aims to understand and map the tourism industry and women's employment mobility in the Special Economic Zone (SEZ) of Mandalika Kuta Lombok, West Nusa Tenggara, Indonesia. This study was a qualitative study using a case study approach with a group analysis unit. Data were obtained through observation, interviews, and documentation. The informants are an optional or criterion-based selection. Informants in this study were 120 informants. Informants were selected using a purposive sampling technique. The informants in this study are not to represent the population but represent information. Data analysis was processed through three stages. The results of the study found that the tourism industry in the Special Economic Zone of Mandalika Kuta Lombok has encouraged the new job creation and job types that were previously unknown by the community. In the category of self-employment and wage employment, there is an increase in the number due to a decrease in the status of casual work. This is a sign that there are significant job changes and job mobility. This is caused by low wages, inconvenience at work, and family factors. With the creation of various types of new jobs and the pattern of employment mobility, the efforts of self-improvement are needed, especially in terms of education and skills. Provincial and District Governments need to conduct a study of the potential and employment opportunities needed for women in the tourism industry to create links and matches between various employment sectors in the tourism industry.

Keywords: Mobility; Special Economic Zone; Tourism Industry; Women's Employment

Copyright (C) 2020. Owned by Author(s), published by Society. This is an open-access article under the CC-BY-NC-SA license. 


\section{Tourism Industry and Women's Employment Mobility in the Special Economic Zone (SEZ) of Mandalika Kuta Lombok}

\section{Introduction}

There are four dimensions to determine whether women participate or are empowered in tourism industry activities, which consist of empowerment from the perspective of 1) economy, 2) social, 3) psychology and 4) politics (Suardana, 2010). According to the UNWTO (World Tourism Organization, A United Nations Specialized Agency) as cited in Teguh (2015), women's involvement in the tourism industry is described as follows: a) Women make up the majority of the formal tourism workforce. b) Women are represented only in service employment and under-represented at the professional level. c) Women in the tourism industry only get $10 \%$ to $15 \%$ less than men. d) The tourism industry makes women as business owners/employers, which is almost double compared to other sectors. e) The proportion of women working in the tourism industry as self-employment/independent workers are higher than in other sectors. f) A large amount of unpaid employment is being run by women in the tourism business.

Research conducted by Suardana (2010) in Kuta Bali found that female workers had more opportunities to work in informal types of businesses such as kiosks (14.3\%), while men were only 9.2\%. Female workers were concentrated in the types of restaurant and souvenir businesses (36.6\%) and food stalls (6.3\%), far above male workers, respectively $21.3 \%$ and $0.8 \%$. Many women are involved in both types of businesses because it does not require special skills. This is confirmed by the results of a study conducted by Wirartha (2000) in an area in which the tourism industry has developed.

The inhabitants in the Special Economic Zone (SEZ) of Kuta Lombok, which is in Central Lombok Regency, West Nusa Tenggara Province, Indonesia, are 903,432 inhabitants. The total inhabitants of women (476,298 inhabitants) are greater than that of men (427,134 inhabitants). Furthermore, the number of inhabitants with an age range 15 years old and over, who have worked in various sectors, were 428,016 inhabitants, consisting of 1) agriculture (230,967 inhabitants), 2) industrial sector, (52,132 inhabitants) 3) trade (49,045 inhabitants), 4 ) services (43,800 inhabitants), and 5) others (52,072 inhabitants). Whereas workforce participation, men are 82.94 while women are 63.61 (Badan Pusat Statistik Provinsi Nusa Tenggara Barat, 2015). This indication shows an imbalance in the distribution of men's and women's roles in entering the workforce. It will lead to various social population issues such as migration, economics, education, health, poverty, unemployment, and employment if it is not handled appropriately.

Noticing the inequality employment accessibility between men and women, then the problem in this study is how the tourism industry encourages women's social mobility, observed from the dimensions of employment mobility, employment status, and the reasons for women to make employment changes. The results of this study are expected to have the urgency of contributing ideas in making policies and developing practical programs related to how the tourism industry can provide opportunities for the mobility of women's employment. Especially for policies, strategies, and programs that are oriented towards empowerment to create a condition that can improve the resource and the living standards of women, also to prevent women workers from marginalization and exploitation, both economically and socioculturally in the community.

\section{Literature Review}

Law of the Republic of Indonesia Number 10 of 2009 on Tourism explained that there are several types of tourism service businesses that can be run by the community such as travel transportation services, travel tours, food and beverage services, providing accommodation, organizing entertainment and recreational activities, tourism information services, tour guides,

Copyright ( ) 2020. Owned by Author(s), published by Society. This is an open-access article under the CC-BY-NC-SA license. https://doi.org/10.33019/society.v8i1.175 


\section{Tourism Industry and Women's Employment Mobility in the Special Economic Zone (SEZ) of Mandalika Kuta Lombok}

water tourism services, as well as businesses that organize tours and water sports, including the provision of facilities and infrastructure as well as other services that managed commercially in waters such as the sea, beaches, rivers, lakes, reservoirs, and spa services (Republik Indonesia, 2009). From the various types of businesses prepared by the tourism industry, all offer new employment for the community, both men and women. This can be interpreted that whether all types of businesses can provide opportunities for women to be able to change employment patterns, from previous employment as farmers, raising livestock, and trading, which can enable the employment mobility.

Employment mobility is defined as someone who changes employment. Current is different from previous employment, both in different fields of business and status. To determine the current and previous employment usually use a certain period. The period itself is no limit (Badan Pusat Statistik, 2010).

To explain the problems of the tourism industry and women's employment mobility, this study used the theory of gender inequality. According to this theory, inequality occurs because of interpretations that consider women to be weaker than men as well as the socio-cultural environment that makes women powerless (Fakih, 2004).

According to the theory of gender inequality, women are subordinated and marginalized to men because women are created to be given different tasks and roles. Biological differences between the sexes and because of different biological functions, they naturally have different social roles and tasks. Natural differences cannot be blamed for inequality between the sexes or the existence of male power over females. For the theory of gender inequality, the oppression of women's gender is a continuation of a structural and cultural exploitation system. This exploitation has implications for the marginalization of women from public life such as economic poverty, education, employment, access to employment, and politics. So that access to capital, money, information, sex, school, self, and authority is in the dominance of men (Ritzer \& Goodman, 2004).

Theoretical exploration conducted by Ritzer \& Goodman (2004) about the relationship between men and women shows that in the micro-social order to the macro, there are differences that cause inequality and lead to marginalization and oppression. This theory assumes inequality and marginalization of women as a result of power relations between men and women, where men have a fundamental and concrete interest to control, use, conquer, and oppress women to carry out their domination. This pattern of oppression will enter the deepest social organization in the structure of domination, namely patriarchy. The concept of patriarchy means the power of the father, originally used to refer to a type of family that is controlled by men. Now it continues to dominate men in all spheres of the community. Patriarchy is the concept that men hold power over all important roles in the community, in government, education, industry, business, employment, health care, religion, family, and women deprived of access to power (Bhasin, 2004).

Efforts to defeat the patriarchal system must begin by instilling awareness in each woman to judge and acknowledge her strength, reject patriarchal pressure that sees women as weak, dependent, and second-class, and fostering fraternity, mutual trust, and caring for one another. The fraternity will bring up efforts to confront patriarchal domination, such as in the business place, at school, at home, in the community, at work, and so on (De Beauvoir, 2005).

Furthermore, the main expression of the theory of gender inequality is that women can claim equality with men based on essential human capacity as a reasonable moral agent. Gender inequality is a result of the sexist and patriarchal patterns of the division of work, and that gender equality can be achieved by changing the division of work through the

Copyright (C 2020. Owned by Author(s), published by Society. This is an open-access article under the CC-BY-NC-SA license. https://doi.org/10.33019/society.v8i1.175 
deconstruction of key institutions in the community such as education, law, economics, and the family. Inequality between men and women is created socially, and social change for equality can be achieved by engaging rational publics and by using state institutions. This theory strongly supports equality in education, equality of responsibility in all lines of social life, and opposes sexism in daily life. So the ideal gender order is individual freedom to choose the most suitable lifestyle and that choice must be accepted and respected by men. Women see this as an ideal that can enhance the practice of freedom and equality as the cultural ideals of all humans, both men, and women (Ritzer \& Goodman, 2004; Mosse, 2004).

To realize gender justice, public awareness, sensitivity, and fairness are needed for gender. The source of the problem of women's poverty lies in a patriarchal culture, superiority of men, and women as subordinates. This patriarchal culture is reflected in family, community, workplace, and state life, and has become a source of justification for the distribution system of authority, decision making systems, work distribution systems, ownership systems, and gender-biased resource distribution systems. Gender bias still occurs because until now the reality of society still prioritizes one particular gender that the degree of men is higher than women. Gender biases can be found in the family, school, public, work, and community environments (Mosse, 2004).

\section{Research Methodology}

This study was conducted in 2018 and funded by the University of Mataram using the NonTax State Revenue budget. This study was qualitative. A qualitative study approach can show about people's lives, behavior, social movements, and kinship relationships. To in-depth study the problem of tourism and the patterns of mobility of women's employment, this study using a case study approach with a group analysis unit. It is used to find and understand what is hidden behind existing phenomena or symptoms (Strauss \& Corbin, 2003). Moleong (2013) stated that research with a qualitative approach can produce an understanding of something that has happened and has been experienced by subjects and informants, which are described in a natural context.

Data were obtained through 1) Observation, by visiting the activities of women workers without being involved in their activities, 2) Interviews, using in-depth interview guides, 3) Documentation, in the form of writing, pictures, diaries which are complementary to the methods of observation and interviews (Sugiyono, 2015). The informants are an optional or criterion-based selection. Informants in this study were 120 informants. Informants were selected using a purposive sampling technique. The informants chosen are women, who are seen as the most aware and understand the problem being studied. To examine the patterns of mobility of women's employment, data analysis was carried out through the following stages: 1) Analyzing the employment and stability of women's employment until the time the study was conducted, 2) Analyzing the pattern of employment mobility in terms of previous employment compared to the current employment (when the study was conducted), 3) Analyzing the status of the previous employment and the status of the current employment (when the study was conducted). Through this process can determine the mobility of women's employment in the tourism industry in the Special Economic Zone (SEZ) of Kuta Mandalika Lombok (Syafruddin et al., 2018). 


\section{Results and Discussion}

\subsection{Tourism Industry and Women's Employment Mobility}

The tourism industry, with its various services, has encouraged the emergence of new employment. Previously, the community only knew about work as farmers, ranchers, and traders. After the area has been developed into a tourism destination, the community has known various activities that can be carried out as jobs such as hotel employees, spas, saleswoman, waiters, kitchen staff and receptionists.

The results of interviews with 120 informants, who worked in the tourism industry in the Special Economic Zone of Mandalika Kuta Lombok found that at the level of education level, $31 \%$ of women had education at the junior high school level and below, $44 \%$ graduated at the senior high school level, and only $25 \%$ have education at the university level.

This data provides information that the level of education of women who choose employment in the tourism industry is still dominated by unskilled workers. They, in general, only have formal education at a lower level and do not have sufficient expertise because they do not have employment experience. Employment that can be done is employment that does not require specific expertise. Such conditions bring benefits to the companies that employ them because unskilled workers have low wages due to the lack of skills they have. Thus, the bargaining power of women is very weak compared to the educated and skilled workers. This unskilled workforce is widely available in the community, even exceeding the required workforce capacity. This gives the company the flexibility to choose workers who are considered to truly meet the requirements and are committed to developing the company. Besides, unskilled workers can only carry out routine work with low levels of initiative and creativity. If there are obstacles, they struggle to find a way out. Unskilled workers are also not good at carrying out their work and responsibilities. Therefore supervisors are needed from the company to produce good work. Women with low levels of education and limited skills have implications for the marginalization of women in public life such as at workplace and access to work, which causes access to information, self, and authority still in the dominance of men (Ritzer \& Goodman, 2004).

Women who work in the tourism industry in the Special Economic Zone (SEZ) of Mandalika Kuta Lombok, in general, work as waiters, receptionists, kitchen staff, and spas. There are also women, who carry out work that does not require special skills such as toilet attendants, food vendors, and handicrafts (see Figure 1 ).

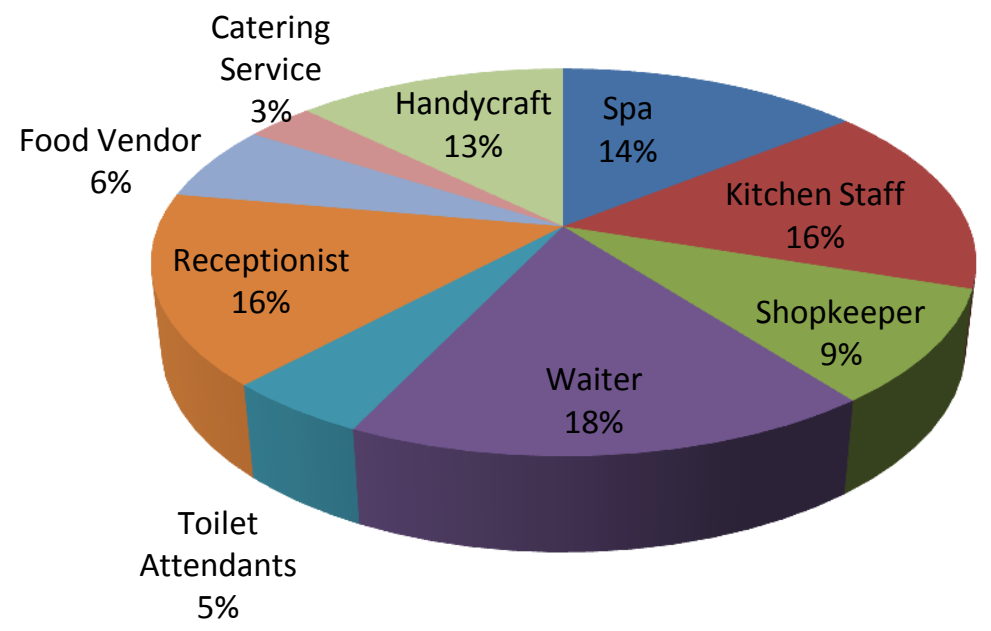

Figure 1. Type of women's employment at the time the study was conducted

Copyright (C 2020. Owned by Author(s), published by Society. This is an open-access article under the CC-BY-NC-SA license. https://doi.org/10.33019/society.v8i1.175 


\section{Tourism Industry and Women's Employment Mobility in the Special Economic Zone (SEZ) of Mandalika Kuta Lombok}

Figure 1 above explained that the tourism industry has many impacts on women, both social and economic. Economic impacts can be direct or indirect impacts or can also be called secondary impacts for those who have an indirect impact, and primary impacts for direct impacts (Suryadana, 2013).

The direct or indirect effect of the tourism industry is the creation of new businesses and activities, which play an important role as employment for women in the Special Economic Zone (SEZ) of Mandalika Kuta Lombok which has been designated as a new prime tourism destination in Indonesia. Its natural and cultural potentials make this destination very promising for employment mobility to occur, especially for improving the welfare of the community. Kanom (2015) found that there were several obstacles in the development of Mandalika Kuta Lombok as a sustainable tourism destination including the low Human Resources (HR) especially in the tourism industry, lack of tourism management, low public awareness in maintaining cleanliness and environmental preservation, and lack of security and comfort.

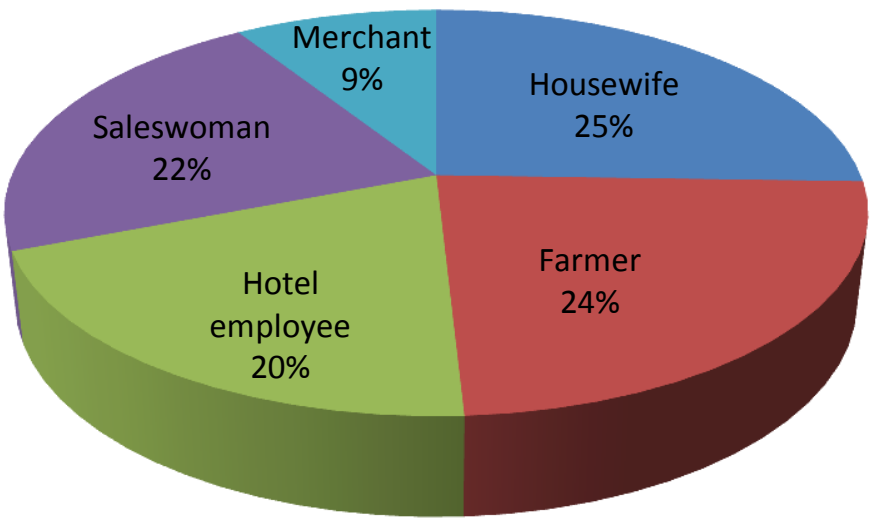

\section{Figure 2. Type of woman's previous employment}

In Figure 1 and Figure 2 there are types of employment that have been carried out by women. In Figure 2 women's employment is still dominated by domestic employment such as housewives, farmers, and traders, while in Figure 1 there is already the mobility of women's employment. This indicates that the tourism industry has provided new insights for women workers, which can provide access to employment. Besides, the tourism industry can also provide multiplier effects which are effects on the economic activities of the community in an area or tourist destination. For example, if a tourist visits Kuta Village in the Special Economic Zone (SEZ) of Mandalika and buys souvenirs in a souvenir shop, the shop owner will get income. The souvenir shop owner will use souvenir sales income to buy souvenir supplies for resale, pay shop staff salaries, finance family needs, pay taxes, electricity and water bills, and others.

In addition to economic impacts, the tourism industry has an impact on socio-cultural life, which consists of a) the creation of new livelihoods related to changes in employment status and the distribution of employment in the community, and in the quantity of expanding employment, b) the occurrence of family modernization, marked by the emergence of a new status of women in traditional farming families. The tourism industry provides equal opportunities for women to obtain employment which has an impact on the increase and distribution of employment and income, and c) social structure differentiation that is closely related to the transition and transformation of the workforce from the agricultural sector to the 
tourism service sector and the development of the tourism industry that produces a variety of tourist needs, thereby contributing to the improvement of the community's welfare (Karmila, 2013; Tuwu, 2018).

Wibowo et al., (2017) stated that the positive impact of tourism industry activities was the creation of various jobs, the addition of income, the accelerated development of infrastructure, and the community was motivated to develop culture and customs to become a cultural attraction which can attract tourists.

\subsection{Women's Employment Status, Previous and After (at the time the study was conducted)}

The employment status of women in this study is divided into 3 categories: 1) Freelance worker, individuals who work alone, and is not committed to the employer for a certain long term or workers carried out by individuals without being bound by contracts with certain companies or people. The work can be done according to the individual's wishes. 2) Entrepreneur. Individuals who can take a business opportunity and the ability to gather the resources needed to generate profits from the business opportunity. 3) Wage employment. Workers with contracts made based on a certain period and can be extended according to certain circumstances.

The data of this study indicate that the employment status of women (before the study was conducted) is dominated by wage employment and status as casual workers (see Table 1). When the study was conducted, there was a mobility of women's employment on the status of wage employment and self-employment. With an increase in the status of wage employment and self-employment as well as a decrease in the status as casual work shows the social mobility of women's employment. Work status shifts can be caused by individual wishes, which are due to getting a better job or can also be caused by being terminated by the employer or work contract has ended (Badan Pusat Statistik, 2010).

Table 1. Women's Employment Status, Previous, and Afterward (at the time the study was conducted)

\begin{tabular}{|clcc|} 
Number & Employment status & $\begin{array}{c}\text { Previous Employment Status } \\
(\boldsymbol{\%})\end{array}$ & $\begin{array}{c}\text { Employment Status } \\
\text { Afterward (\%) }\end{array}$ \\
\hline $\mathbf{1}$ & Freelancer & 33.3 & 9.5 \\
\hline $\mathbf{2}$ & Entrepreneur & 12.7 & 19 \\
\hline $\mathbf{3}$ & Wage Employment & 53.9 & 71.4 \\
\hline & Total & 100 & 100 \\
\hline
\end{tabular}

The social mobility of women's employment occurs because of changes in work status at the same level or changes to higher or lower levels or at different types of employment. The study data shows that the status of casual work before the study was conducted, was quite large at $33.3 \%$ and decreased by $9.5 \%$ when the study was conducted. This data shows there is a change in employment status that marks the occurrence of employment status mobility, which is vertically oriented consisting of an increase in entrepreneur status from $12.7 \%$ to $19 \%$, as well as wage employment status from $53.9 \%$ to $71.4 \%$. The social mobility of employment status that occurs shows the high accessibility of the community, and then it provides convenience in the social movement of the community, especially in socio-economic activities. The existence of the 
tourism industry in the Special Economic Zone (SEZ) of Mandalika Kuta Lombok is very helpful to the local community in terms of employment.

This result is supported by research conducted by Sismudjito et al., (2018) found that the development of the tourism industry can provide new employment and livelihood opportunities for the community who were previously unaware of the tourism industry. The tourism industry can provide new knowledge about employment, which is not only focused on agriculture and can help the community's economy and can increase income to meet family needs. The existence of an industry, both the manufacturing industry and the service industry, can encourage the interest of women to do employment mobility, especially for women who previously worked as farmers and housewives to turn into workers in industrial services (Wibowo et al., 2017).

\subsection{Reason for Changing the Employment}

This study found that there are 6 basic reasons the women for changing employment, which consisted of low salary/wage, inconvenient work, finding new experiences, family reasons, workplaces far from home, and workplaces evicted (see Figure 3).

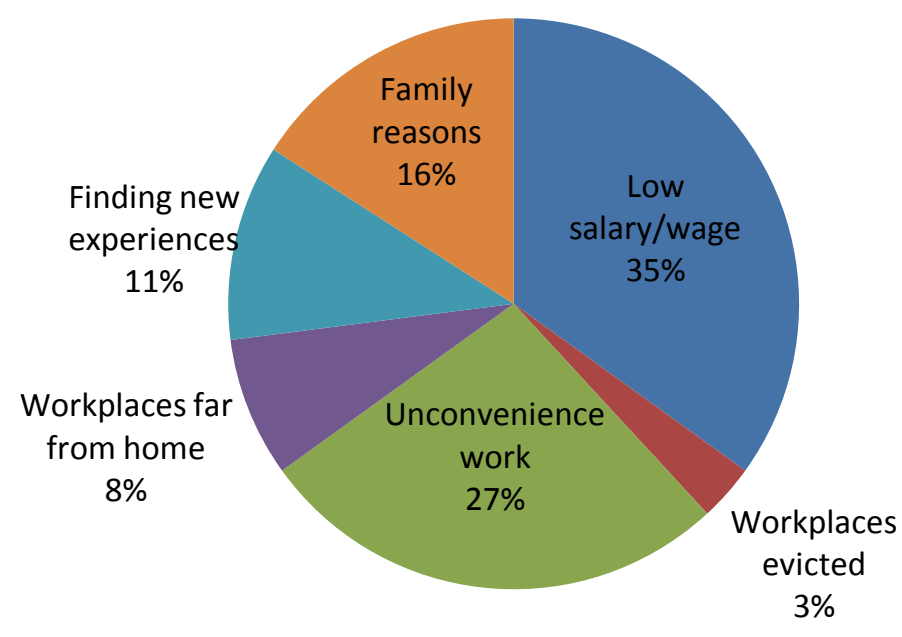

Figure 3. Basic reasons for changing the employment

Further, research found that in terms of frequency of changing the employment, $50.9 \%$ had changed 2 times, $23.5 \%$ had changed once, $13.7 \%$ had changed 3 times, and 11.8 had changed 4 times. The factor of changing employment due to low salary/wage is a common issue for workers. The issue of salary/wage has always been the main annual agenda, which is fought by workers in Indonesia. Factually, salaries/wages of workers are not proportional compared to the cost of the basic needs of workers. Protection and improvement of the welfare of women workers are still not considered by employers. This encourages women workers to change their employment to look for more income or large wages (Sulistyono, 2011; Yusrini, 2017). This is due to wage discrimination, both explicitly and implicitly which manipulates gender ideology as a justification (Susiana, 2017). This is due to the strong patriarchal culture, which is reflected in social life and the workplace, as well as sources of justification for the authority distribution system, work distribution system, and resources distribution system (Mosse, 2004). Until now, the reality of society still prioritizes one particular sex; the degree of men is higher than women. Women are still considered "the second sex" in socio-cultural life (De Beauvoir, 2005). 


\section{Tourism Industry and Women's Employment Mobility in the Special Economic Zone (SEZ) of Mandalika Kuta Lombok}

Then, the results of the study show that the basic reason for women to change employment was the problem of inconvenience at work. This point is a scary thing for a woman in the workplace. This is due to the many cases of physical assault and harassment experienced by women. In some cases of sexual harassment at work, most women do not want to report the incident, because they are afraid of losing their employment. Inequality also often occurs when married women are still considered single, even though these women are the main breadwinners in their families. Besides, there is also the recruitment of women workers specifically single and are not allowed to give birth within a certain period. Maternity rights are also a problem, which is often found in industrial relations in the workplace. In some cases, not a few women are forced to resign or change employment (Susiana, 2017). For the theory of gender inequality, this can occur because of the oppression of women's gender that comes from exploitation systems that are structural and cultural (Ritzer \& Goodman, 2004).

The study also found that the reason for changing employment was a family factor. In a patriarchal culture of society, which does not support women to work, they will collide with traditional culture in the community. Often, when the wife works outside the home, her husband and parents will forbid her from working. The reason is that women and wives should work at home to serve their husbands and take care of their children. When children become neglected, children's health is not good, or their children's school performance decreases, the problem will be borne by the wife. In the theory of gender inequality that women are marginalized because women are naturally created to be given different tasks and roles. This has implications for the marginalization of women from public life such as economic poverty and access to employment (Sutrisna, 2011). This is because, in traditional families, women who work are still underestimated. Women's work is seen as more than fulfilling their needs rather than earning an income (Moose, 2004).

\section{Conclusion}

The tourism industry has encouraged the creation of new types of employment for women. Previously they only knew about employment as housewives, farmers, and breeders. Today, with the tourism industry, they know and work in various types of employment such as saleswoman, spas, receptionists, handicrafts, and hotel employees. In the aspect of employment mobility, there has been a change in the status of wage employment and self-employment, which was previously dominated by the status of contract/casual work. For all categories of employment status, there has been a significant change as a sign that there has been the mobility of women's employment status. The study also found that the main reasons for women to change employment were due to low salary/wage, inconvenience at work, and family reasons. With the development and creation of new employment in the tourism industry in the Special Economic Zone (SEZ) of Mandalika Kuta Lombok and the mobility of women's employment status, women are urgently needed to improve their capacity, especially in terms of education and skills. Provincial and District Governments need to conduct a study of the potential and employment opportunities needed for women in the tourism industry to create links and matches between various employment sectors in the tourism industry.

\section{Acknowledgment}

The authors would like to thank the Rector of University of Mataram for providing research funding, sourced from internal university funds (Non-Tax State Revenue or PNBP), through the Research Capacity Building Program, the funding year 2018, document number 1461.Q/UN.L1/PP/2018, and the Institute for Research and Community Service of the

Copyright (C 2020. Owned by Author(s), published by Society. This is an open-access article under the CC-BY-NC-SA license. 
University of Mataram which has recommended to conduct this study. The authors also thank all the informants who provided assistance and information during the study conducted.

\section{Declaration of Conflicting Interests}

The authors declared no potential conflicts of interest concerning the study, authorship, and/or publication of this article.

\section{References}

Badan Pusat Statistik. (2010). Survei Angkatan Kerja Nasional (SAKERNAS), 2010. Retrieved from https:/ / sirusa.bps.go.id/ sirusa/index.php/dasar/view?kd=5\&th=2010

Badan Pusat Statistik Provinsi Nusa Tenggara Barat. (2015). Nusa Tenggara Barat Dalam Angka 2015. Retrieved from

https://ntb.bps.go.id/publication/2015/11/10/65c71e04a1f25baebfd01d1b/nusatenggara-barat-dalam-angka-2015.html

Bhasin, K. (2004). Menggugat Patriarki. Yogyakarta: Yayasan Bentang.

De Beauvoir, S. (2005). The Second Sex: Kehidupan Perempuan. Jakarta: Pustaka Promethea.

Fakih, M. (2004). Analisa Gender E Transformasi Sosial. Yogyakarta: Pustaka Pelajar.

Kanom, K. (2015). Strategi Pengembangan Kuta Lombok Sebagai Destinasi Pariwisata Berkelanjutan. Jurnal Master Pariwisata (JUMPA), 1(2), 25-42. https:// doi.org/10.24843/JUMPA.2015.v01.i02.p03

Karmila, M. (2013). Peran Ganda Perempuan di Lingkungan Pariwisata Bandungan, Jawa Tengah. PALASTREN Jurnal Studi Gender, 6(1), 129-158. http://journal.stainkudus.ac.id/index.php/Palastren/article/view/981

Moleong, L. J. (2013). Metode Penelitian Kualitatif. Bandung: Remaja Rosdakarya.

Mosse, J. C. (2004). Gender E Pembangunan. Yogyakarta: Pustaka Pelajar.

Republik Indonesia. (2009). Undang-Undang Republik Indonesia Nomor 10 Tahun 2009 Tentang Kepariwisataan. Lembaran Negara Republik Indonesia Tahun 2009 Nomor 11. Jakarta: Kementerian Hukum dan Hak Asasi Manusia Republik Indonesia.

Ritzer, G., \& Goodman, D. J. (2004). Teori Sosiologi Modern. Jakarta: Prenada Media.

Sismudjito, S., Pohan, S., \& Kariono, K. (2018). Mobilitas Sosial Penduduk Berbasis Industri Pariwisata Dalam Meningkatkan Status Sosial Ekonomi Masyarakat di Kota Gunung Sitoli, Nias Propinsi Sumatera Utara. Talenta Conference Series: Local Wisdom, Social, and Arts (LWSA), 1(1), 203-213. https:// doi.org/10.32734/lwsa.v1i1.164

Strauss, A., \& Corbin, J. (2003). Dasar-dasar Penelitian Kualitatif, Prosedur, Teknik dan Teori Grounded. Surabaya: Bina Ilmu.

Suardana, I. W. (2010). Pemberdayaan Perempuan di Kawasan Kuta Sebagai Upaya Peningkatan Kualitas Pariwisata Bali. Piramida, 4(2), 56-64.

Sugiyono, P. (2015). Metode Penelitian Kombinasi (Mixed Methods). Bandung: Alfabeta.

Sulistyono, S. S. W. (2011). Mobilitas Tenaga Kerja dari Sektor Pertanian ke Sektor Non Pertanian di Kecamatan Lawang Kabupaten Malang. Jurnal Ekonomi Pembangunan, 9(2), 134-155. https://doi.org/10.22219/jep.v9i2.3670

Suryadana, L. M. (2013). Sosiologi Pariwisata. Bandung: Humaniora.

Susiana, S. (2017). Pelindungan Hak Pekerja Perempuan dalam Perspektif Feminisme. Jurnal Aspirasi, 8(2), 207-221. http://jurnal.dpr.go.id/index.php/aspirasi/article/view/1266 
Sutrisna, E. (2011). Problematika Perempuan Bekerja di Sektor Pariwisata (Studi Kasus $\begin{array}{llll}\text { Perhotelan). Jurnal Aplikasi } & \text { Bisnis, }\end{array}$ https://jab.ejournal.unri.ac.id/index.php/JAB/article/view/905

Syafruddin, S., Wadi, H., \& Suud, S. (2018). Kepariwisataan Dan Pola Mobilitas Pekerjaan Perempuan Di Kawasan Wisata Kuta Mandalika Kabupaten Lombok Tengah (Laporan Penelitian). Mataram: Lembaga penelitian dan Pengabdian pada Masyarakat Universitas Mataram.

Teguh, F. (2015). Tata Kelola Destinasi Pembangunan Ekosistem Parawisata. Yogyakarta: Gadjah Mada University Press.

Tuwu, D. (2018). Peran Pekerja Perempuan Dalam Memenuhi Ekonomi Keluarga: Dari Peran Domestik Menuju Sektor Publik. Al-Izzah: Jurnal Hasil-Hasil Penelitian, 13(1), 63-76. http://dx.doi.org/10.31332/ai.v13i1.872

Wibowo, S., Rusmana, O., \& Zuhelfa, Z. (2017). Pengembangan Ekonomi Melalui Sektor Pariwisata Tourism. Jurnal Kepariwisataan: Destinasi, Hospitalitas dan Perjalanan, 1(2), 83-89. https:// doi.org/10.34013/jk.v1i2.13

Wibowo, Y. A., Rusdarti, R., \& Handoyo, E. (2017). Mobilitas Perempuan Buruh Pabrik dalam Perubahan Sosial Ekonomi Perempuan Buruh (Studi Kasus di Desa Batursari Kecamatan Mranggen Kabupaten Demak). Journal of Educational Social Studies, 6(1), 73-80. https://journal.unnes.ac.id/sju/index.php/jess/article/view/16262

Wirartha, I. M. (2000). Ketidakadilan Jender Yang Dialami Pekerja Perempuan Di Daerah Pariwisata. SOCA: Jurnal Sosial Ekonomi Pertanian, 0(1), 1-11. Retrieved from https://ojs.unud.ac.id/index.php/soca/article/view/3979

Yusrini, B. A. (2017). Tenaga Kerja Wanita dalam Perspektif Gender di Nusa Tenggara Barat. AL-MAIYYAH: Media Transformasi Gender dalam Paradigma Sosial Keagamaan, 10(1), 115-131. http:/ / ejurnal.iainpare.ac.id/index.php/almaiyah/article/view/452

\section{About the Authors}

1. Syafruddin, obtained his Doctoral degree in Social Science from Airlangga University, Indonesia, in 2005. The author is an Associate Professor at the Department of Sociology Education, Faculty of Teacher Training and Education, University of Mataram, Indonesia. E-Mail: syafruddin_fkip@unram.ac.id

2. Hairil Wadi, obtained his Magister degree in Social Science Education from State University of Yogyakarta, Indonesia, in 2009. The author is an Assistant Professor at the Department of Sociology Education, Faculty of Teacher Training and Education, University of Mataram, Indonesia.

E-Mail: wadifkipunram@gmail.com

3. Suud, obtained his Magister degree in Sociology from Padjadjaran University, Indonesia, in 2001. The author is an Associate Professor at the Department of Sociology Education, Faculty of Teacher Training and Education, University of Mataram, Indonesia.

E-Mail: suud.fkip@unram.ac.id 